\title{
MENGUNGKAP PERSEPSI WAJIB PAJAK ATAS PENDAMPINGAN RELAWAN PAJAK
}

\author{
I Nyoman Putra Yasa ${ }^{1)}$, Ni Made Ayu Sri Putri Artini ${ }^{2)}$, \\ Luh Melly Astari ${ }^{3)}$, Ni Putu Purnama Sari ${ }^{4)}$ \\ ${ }^{1,2,3,4)}$ Universitas Pendidikan Ganesha \\ Email: putrayasainym@undiksha.ac.id
}

Diterima 14 Desember 2020 / Disetujui 25 Februari 2021

\begin{abstract}
The purpose of this research to explore the perceptions of taxpayers on the satisfaction of assistance performed by tax volunteers at the Tax Volunteer placement location. There are 4 (four) locations for the placement of Tax Volunteers, namely KPP Pratama Singaraja, KP2KP Negara, KP2KP Amlapura and Tax Center Undiksha. This research use desciptive qualitative approach. The sampling technique used in this research was purposive sampling with interview techniques in collecting research data. The population in this research are taxpayers who carry out the duty to annual tax return through e-Filing. Meanwhile, the sample in this research were taxpayers whose reporting the annual tax return were assisted by Tax Volunteers in the 4 (four) placements. The results of this research indicate that taxpayer assistance activities by tax volunteers in helping to fill individual annual tax returns are very effective. This can be seen from the satisfaction of taxpayers after receiving assistance by Tax Volunteers. Taxpayers are satisfied with the assistance of tax volunteers because the annual tax return reporting process is easier, faster and Tax Volunteers are able to guide Taxpayers in filling out their own. This assistance helps reduce the difficulties experienced by Taxpayers in understanding SPT filling independently. Taxpayer satisfaction is expected to increase compliance in reporting the Annual Tax Return. The sustainability of the Tax Volunteer program is also highly expected because it is considered very effective for taxpayers who do not understand the procedures for submitting annual tax return, especially those who are not yet competent with technological advances.
\end{abstract}

Keywords: Perception, Assistance, e-Filing, Tax Volunteers

ABSTRAK: Penelitian ini bertujuan untuk menggali persepsi wajib pajak atas kepuasan pendampingan yang dilakukan oleh Relawan Pajak di lokasi penempatan relawan pajak. Adapun 4 (empat) lokasi penempatan Relawan Pajak yaitu KPP Pratama Singaraja, KP2KP Negara, KP2KP Amlapura dan Tax Center Undiksha. Penelitian ini menggunakan pendekatan deskriptif kualitatif. Teknik penentuan sampel yang digunakan dalam penelitian ini adalah purposive sampling dengan teknik wawancara dalam pengumpulan data penelitian. Yang menjadi populasi dalam penelitian ini adalah Wajib Pajak yang melaksanakan kewajiban dalam melaporkan SPT Tahunan melalui E-Filing. Sedangkan, sampel dalam penelitian ini yakni Wajib Pajak yang kegiatan pelaporan SPT Tahunannya didampingi oleh Relawan Pajak di 4 (empat) penempatan tersebut. Hasil penelitian ini menunjukan bahwa kegiatan pendampingan wajib pajak oleh relawan pajak dalam membantu pengisian SPT tahunan orang pribadi sangat efektif. Hal ini dapat dilihat dari kepuasan wajib pajak setelah mendapatkan pendampingan oleh relawan pajak. Wajib Pajak puas atas pendampingan relawan pajak dikarenakan proses pelaporan SPT Tahunan menjadi lebih mudah, cepat dan para relawan pajak mampu menuntun wajib pajak dalam pengisian SPT-nya. Pendampingan ini membantu mengurangi kesulitan yang dialami Wajib Pajak dalam memahami pengisian SPT secara mandiri. Kepuasan Wajib Pajak diharapkan mampu meningkatkan kepatuhan dalam pelaporan SPT Tahunan. Keberlanjutan program relawan pajak juga sangat diharapkan karena dinilai sangat efektif bagi wajib pajak yang belum mengerti tata cara penyampaian SPT khususnya yang belum cakap akan kemajuan teknologi.

Kata kunci: Persepsi, Pendampingan, E-Filing, Relawan Pajak

\section{Pendahuluan}

Indonesia dalam melakukan Pembangunan Nasional memiliki beberapa sumber penerimaan Negara diantaranya pajak, pinjaman dalam negeri dan luar negeri, hibah, serta Penjualan sumber daya alam (DJPPR, 2017). Sumber tersebut memiliki risikonya masing-masing seperti 
halnya pinjaman dalam negeri dan luar negeri dapat memberatkan posisi APBN yang harus dibayar beserta bunganya oleh negara. Selain itu, meskipun Indonesia mempunyai sumber daya alam yang melimpah tetapi, apabila terus dijual secara berlebihan akan berdampak pada kerusakan lingkungan dan habisnya sumber daya alam tersebut. Berbeda dengan pajak yang merupakan sumber pendapatan minim risiko dan dapat berpengaruh terhadap peningkatan kemandirian bangsa karena Indonesia secara otomatis akan memperoleh pendapatan dari warga negaranya sendiri. Sebagian besar kegiatan negara dibiayai oleh pajak. Pembangunan infrastruktur seperti jalan raya, sekolah, jembatan, rumah sakit/ puskesmas hingga kantor polisi akan sulit untuk dilaksanakan apabila tidak ada pajak (Dwipayana dkk,2017).

Direktorat Jenderal Pajak memiliki peran sangat penting dalam merealisasikan upaya-upaya negara di bidang perpajakan, hal ini bertujuan untuk mengupayakan pendapatan dari sektor pajak mengalami kenaikan. Salah satu upaya yang telah dilakukan oleh Pemerintah yakni melakukan reformasi perpajakan (tax reform) yang meliputi penyempurnaan sistem serta mekanisme perpajakan yang merubah sistem pemungutan pajak dari Official Assessment System menjadi Self Assesment System. Menurut Jatmiko (2006), Self Assesment System merupakan suatu sistem dimana wajib pajak mempunyai kewajiban dalam menghitung, memperhitungkan, membayar serta melaporkan surat pemberitahuan (SPT) secara benar, lengkap dan tepat waktu. Sistem ini berarti, wajib pajak mempunyai wewenang dalam menghitung, memperhitungkan, membayar hingga melaporkan surat pemberitahuan (SPT) secara benar, lengkap dan tepat waktu. Mardiasmo (2011) mengungkapkan beralihnya sistem tersebut bukan karena salah satu sistem tersebut lebih baik, melainkan ini merupakan bentuk upaya Pemerintah dalam menyesuaikan sistem perpajakan dengan melihat perubahan sistem perekonomian dan perkembangan dalam masyarakat. Dari tahun ke tahun belum menunjukkan peningkatan yang signifikan terhadap kepatuhan wajib pajak dalam memenuhi kewajiban perpajakannya (Tawas dkk., 2016). Menurut Wulan dkk.(2015), kepatuhan perpajakan merupakan suatu tindakan wajib pajak dalam memenuhi kewajiban perpajakannya berdasarkan ketentuan peraturan pelaksanaan perpajakan dan peraturan perundang-undangan yang berlaku pada suatu negara.

Kesadaran diartikan sebagai keadaan mengetahui atau mengerti suatu hal, sedangkan perpajakan merupakan segala hal yang berkaitan dengan pajak. Sehingga kesadaran membayar pajak adalah keadaan dalam mengetahui ataupun mengerti segala sesuatu yang berkaitan dengan pajak termasuk membayar pajak (Jotopurnomo \& Mangoting, 2013). Masyarakat akan mematuhi kewajiban perpajakannya apabila terdapat penilaian positif atas pelaksanaan fungsi negara yang dilaksanakan oleh pemerintah. Maka dari itu, kesadaran wajib pajak mengenai perpajakan sangat dibutuhkan dalam meningkatkan kepatuhan wajib pajak (Jotopurnomo \& Mangoting, 2013). Permasalahan yang terjadi saat ini yaitu masyarakat yang telah memenuhi syarat sebagai wajib pajak belum melaksanakan kewajiban perpajakannya secara penuh. Menurut Julita (2020), pada tanggal 10 Maret 2020 masih ada 13 Juta Wajib Pajak yang belum melaporkan SPT-nya. Menurut Suherman (2015) menyebutkan bahwa Surat Pemberitahuan adalah surat yang oleh wajib pajak digunakan untuk melaporkan perhitungan dan/atau harta dan kewajiban sesuai dengan ketentuan peraturan perundang-undangan perpajakan. Pada hakikatnya, wajib pajak hendaknya memenuhi kewajibannya seperti, mendaftarkan diri, menghitung, membayar serta melaporkan pajaknya (DJP, 2020). Kewajiban pajak diartikan sebagai kewajiban yang melekat bagi setiap warga negara yang telah memenuhi kualifikasi untuk membayar pajak, dan ikut serta dalam membantu Pemerintah untuk membangun negara dan mensejahterakan masyarakat (Faisol dkk., 
2019). Kewajiban pelaporan pajak adalah tahapan yang sering dilewatkan karena beberapa alasan seperti adanya asumsi bahwa tidak perlu melapor karena sudah membayar, kesulitan dalam pelaporan yang saat ini dilakukan secara online serta pengenaan sanksi denda yang nominalnya terbilang kecil (Uly, 2019).

Pelaporan Surat Pemberitahuan (SPT) dilaksanakan paling lambat tiga bulan setelah akhir tahun pajak, hal tersebut telah dicantumkan dalam Undang-Undang Nomor 28 Tahun 2007 mengenai Ketentuan Umum dan Tata Cara Perpajakan (KUP). Dengan adanya fenomena ini, DJP berupaya meningkatkan kesadaran WP dalam melaporkan SPT-nya. DJP bekerjasama dengan perguruan tinggi terkait pembentukan Tax Center hingga meluncurkan program relawan pajak. Program Relawan Pajak merupakan suatu kegiatan untuk menanamkan kesadaran pajak kepada mahasiswa sebagai suatu upaya Direktorat Jendral Pajak dengan Kemendikbud (Utami, 2019). Relawan Pajak (Tax Volunteer) di Indonesia adalah sebuah perkumpulan atau komunitas yang mendalami ilmu perpajakan serta mengabdi kepada masyarakat melalui kegiatan pendampingan pelaporan SPT (Dwianika \& Sofia, 2019). Direktorat Jenderal Pajak menekankan bahwa, program ini melibatkan pihak ketiga dalam hal ini mahasiswa untuk membantu kegiatan penyuluhan dalam meningkatkan kepatuhan wajib pajak. Mekanisme dilaksanakannya program ini meliputi proses uji coba yang telah distandarisasi yaitu pendaftaran, pelatihan, penyeleksian, dan pendayagunaan Relawan Pajak. Organisasi Mitra di seluruh Indonesia yang menaungi program ini bernama Tax Center. Hal itu berdasarkan Nota Kesepahaman MenKeu dengan MenRistekdikti Nomor MoU4/MK.03/2016 dan Nomor 7/M/NK/2016, terkait Peningkatan Kerja Sama Perpajakan. Pada tahun 2020, Universitas Pendidikan Ganesha (UNDIKSHA) mendapat kesempatan bekerja sama dengan DJP untuk merealisasikan program relawan pajak khususnya di wilayah Bali Utara. Relawan pajak nantinya akan bertugas mendampingi wajib pajak dalam melaporkan pajaknya secara online melalui layanan $e$-filing.

Relawan Pajak terdiri atas mahasiswa/i Universitas terpilih sebagai bagian dari generasi millenial yang diasumsi lebih cepat menyesuaikan diri dengan arus perkembangan IPTEK. Adapun tugas dari Tax Volunteers yakni memberikan pelayanan secara langsung kepada WP dalam bentuk pendampingan penyampaian Surat Pemberitahuan Tahunan melalui layanan e-filling. E-filling adalah salah satu kemudahan yang disediakan oleh DJP untuk membantuWP dalam penyampaian Surat Pemberitahuan (SPT). Sebagai upaya adaptasi kemajuan teknologi di bidang perpajakan, Direktorat Jendral Pajak meluncurkan sistem e-filing yang sekiranya dapat memberikan mutu pelayanan yang lebih sederhana, cepat, efisien dan lebih baik bagi WP sehingga kepatuhan WP dalam melakukan kewajibannya diharapkan dapat meningkat (Gekonge, 2016). Utamanya, e-filing digunakan untuk meningkatkan pelayanan kepada publik dengan memberikan fasilitas penyampaian SPT secara elektronik melalui media internet kepada WP.

Menurut Tene, dkk (2017) menerangkan ada 2 kiat-kiat kepatuhan yang berkaitan dengan pelayanan yaitu menjalankan tanggung jawab secara selaras untuk menawarkan kemudahan pelayanan yang terbaik (make it easy) serta menawarkan penunjang pelayanan dan pencerahan bagaimana mengetahui ketentuan perpajakan dan tata cara administrasi yang menyertainya dengan benar (assist to comply). Hal ini dapat dikaitkan dengan sebuah teori yaitu Contrast Theory yang disampaikan oleh Larassaty (2016). Contrast Theory adalah teori yang memaparkan mengenaikeadaan kepuasan pelanggan dari perspektif psikologi. Teori ini menggambarkan proses penilaian konsumen setelah menggunakan atau merasakan suatu produk atau jasa yang menggambarkan perbandingan antara hasil dengan prediksi konsumen diawal 
(Tjiptono, 2008:170). Menurut Tjiptono (2008:170), Contrast Theory ini akan menggabarkan perbedaan antara ekspektasi konsumen diawal dengan kenyataan produk/ jasa. Hal ini berarti, ketika kenyataan melampaui ekspektasi, maka konsumen akan merasa sangat puas. Namun ketika kenyataan produk dibawah ekspektasi, maka konsumen akan sangat tidak puas. Hal ini berarti bahwa konsumen sangat sensitif terhadap ekpektasi yang tidak terpenuhi dan bisa bereaksi secara berlebihan.

Penelitian ini didasari dengan fenomena rendahnya kepatuhan wajib pajak dalam melaporkan SPT Tahunan karena berbagai faktor seperti kurangnya pemahaman pelaporan SPT melalui layanan e-filing. Yasa, dkk (2019) menyatakan bahwa, rendahnya kepatuhan WP terihat dari tax ratio suatu negara. Tax ratio Indonesia sendiri sebesar $11,6 \%$ pada tahun 2015 dan mengalami penurunan menjadi 10,7\% pada tahun 2017. Agustiningsih \& Isroah (2016) dalam penelitiannya menyimpulkan bahwa efektivitas dalam penggunaan e-filing dipengaruhi oleh tingkat penafsiran WP yang masih sedikit mengenai sistem e-filing, akibatnya kuantitas WP yang belum patuh cukup besar dalam pelaporan SPT tahunannya. Maksimalnya kepatuhan WP dalam pelaporan SPT diupayakan dengan adanya program Relawan Pajak dari DJP yang bertugas dalam hal pendampingan pelaporan. Penelitian ini kemudian mencoba untuk menggali persepsi wajib pajak terkait pendampingan pelaporan SPT Tahunan yang dilakukan para relawan pajak. Penelitian ini diharapkan mampu untuk menggali sejauh mana persepsi wajib pajak terhadap pendampingan yang diberikan oleh relawan, selain itu penelitian ini akan digunakan untuk memberi masukan kepada DJP Kanwil Bali terkait pengembangan serta sebagai evaluasi program relawan pajak kedepannya.

\section{Metode Penelitian}

Penelitian berlokasi di 4 (empat) lokasi penempatan Relawan Pajak yaitu KPP Pratama Singaraja, KP2KP Negara, KP2KP Amlapura dan Tax Center
Undiksha. Dalam mengumpulkan data, peneliti menggunakan pendekatan deskriptif kualitatif. Penelitian deskriptif menurut Arikunto (2010) yakni penelitian yang diartikan untuk menjelajah keadaan atau kondisi, di mana hasilnya disajikan dalam bentuk laporan. Penelitian deskriptif kualitatif dikerjakan dengan mendeskripsikan permasalahan yang telah teridentifikasi dan dibatasi pada sejauh mana upaya untuk mengungkap permasalahan dan kondisi sebagaimana adanya, sehingga merupakan pengungkapan kebenarankebenaran yang ada (Sugiono, 2012). Metode ini secara signifikan bisa mengendalikan substansi penelitian. Hal tersebut berarti bahwa metode kualitatif memaparkan secara langsung kaitan antara peneliti dan narasumber, objek dan subjek penelitian.

Populasi adalah sekumpulan objek atau subyek yang mempunyai kuantitas serta karakter yang diterapkanpenelitiguna mempelajarinya, lalu menarik kesimpulannya oleh peneliti (Sugiono,2012). Yang menjadi populasi pada penelitian ini yakni WP yang melaksanakan kewajiban penyampaian SPT Tahunan lewat E-filling di KPP Pratama Singaraja, KP2KP Negara, KP2KP Amlapura dan Tax Center Undiksha yang terdiri atas WPOP yang memakai blangko SPT Tahunan 1770, 1770S dan 1770SS. Sedangkan sampel merupakan bagian dari jumlah serta karakteristik yang dipunyai oleh populasi tersebut (Sugiono, 2007). Sampel yang digunakan adalah WP yang kegiatan pelaporan SPT Tahunannya didampingi oleh Relawan Pajak di 4 (empat) penempatan tersebut. Teknik pengumpulan data pada penelitian ini memakai metode purposive sampling dengan melakukan wawancara secara online kepada sampel yang memenuhi kriteria yaitu, WP yang menyampaikan SPT Online dan pernah menggunakan jasa pendampingan Relawan Pajak baik di KPP Pratama Singaraja, KP2KP Negara, KP2KP Amlapura dan Tax Center Undiksha.

Data dalam penelitian ini bersumber dari data primer. Menurut Sekaran (2013) menyatakan bahwa data primer merupakan data yang didapat dari tangan pertama atau 
dari sumbernya langsung. Data primer pada penelitian ini merupakan hasil wawancara kepada beberapa responden yaitu para wajib pajak yang telah didampingi oleh relawan pajak. Indikator yang diukur dalam penelitian ini yaitu:

1. Kebermanfaatan

Kebermanfaatan menurut Venkatesh dan Davis (2000:201) adalah suatu tingkatan dimana seseorang meyakini bahwa penggunaan sistem tertentu akanbisa meningkatkan pencapaian kerja orang tersebut. Dalam penelitian ini, indikator kebermanfaatan antara lain:
a. Meningkatkan kinerja
b. Menambah tingkat produktivitas
c. Meningkatkan efektivitas kinerja
d. Sistem bermanfaat

2. Kemudahan

Kemudahan Penggunaan menurut Venkatesh dan Davis (2000:201) adalah suatu tingkatan keyakinan dimana seseorang percaya bahwa penggunaan yang khusus tersebut dapat dengan mudah untuk dapat dipahami. Dalam penelitian ini, indikator kemudahan penggunaan antara lain:

a. Sistem jelas dan mudah dimengerti

b. Tidak dibutuhkan banyak usaha

c. Sistem mudah digunakan

d. Sistem fleksibel

\section{Hasil dan Pembahasan}

Relawan Pajak (Tax Volunteers) di Universitas Pendidikan Ganesha dibentuk menjadi sebuah komunitas di bawah Organisasi Tax Center UNDIKSHA. Komunitas ini terdiri atas 42 orang relawan pajak yang kemudian dibekali beberapa ilmu dan pelatihan oleh petugas pajak dari Direktorat Jenderal Pajak Kanwil Bali sebelum nantinya akan mengabdi kepada masyarakat khususnya di 4 (empat) wilayah penempatan relawan. Setelah dilaksanakan pelepasan relawan pajak ke lapangan, kinerja mereka akan memberi dampak kepada kepuasan WP selaku masyarakat serta berdampak pula kepada nama baik lembaga DJP yang merupakan pihak penanggungjawab program ini. Menyangkut program relawan pajak ini, peneliti bermaksud untuk mengungkap persepsi wajib pajak melalui wawancara secara online dengan beberapa orang berdasarkan indikator penelitian. Seperti halnya disebutkan pada bagian metodologi, responden yang dimaksud adalah WP yang melaporkan SPT Online (e-filling) serta pernah menggunakan jasa pendampingan Relawan Pajak UNDIKSHA. Hasil penelitian menunjukkan bahwa $100 \%$ responden merasa bahwa pendampingan oleh relawan pajak bermanfaat serta $73 \%$ responden merasakan kemudahan dari adanya pendampingan oleh relawan pajak.

Dari hasil wawancara dengan I Putu AD (28) yang merupakan wajib pajak baru sehingga pertama kali membuat laporan SPT, beliau sangat terbantu dengan adanya program relawan pajak ini. Relawan pajak sangat runtut dalam memberikan pemahaman berkaitan dengan pengisian SPT sehingga sedikit mengerti tata cara pelaporan SPT secara online. Selain itu juga, keberadaan program ini mengatasi permasalahan antrian panjang di Kantor Pajak untuk pelaporan SPT. Program ini efektif dilakukan setiap tahun karena masih banyak wajib pajak yang belum mengerti tata penyampaiannya apalagi yang belum cakap teknologi. Menurut Kadek RS (37) selaku narasumber dalam penelitian ini mengutarakan bahwa pendampingan yang dilakukan oleh relawan pajak sangat memuaskan. Pelaporan SPT secara online menjadi lebih mudah. Program ini sangat efektif dilakukan untuk membantu wajib pajak yang masih belum paham terkait pelaporan SPT secara online. Beliau juga menyampaikan agar program relawan pajak ini lebih dikenal masyarakat luas ada baiknya dilakukan sosialisasi yang lebih gencar lagi baik melalui sosial media atau media lainnya. Serta diharapkan program ini terus dilaksanakan hingga membuat wajib pajak mampu melaporkan SPT secara mandiri. Penyataaan lain diungkapkan oleh Ibu LE (64) yakni beliau menyatakan bahwa mahasiswa yang menjadi relawan pajak sangat terampil dalam membantu pelaporan SPT. Pelayanan yang diberikan ketika melakukan pendampingan sangat cepat. Namun, perlu ditingkatkan pula keterampilan dari masing-masing relawan 
sehingga memiliki kemampuan yang sama. Program ini kembali diharapkan hadir setiap tahunnya guna membantu wajib untuk melaporkan SPT.

Guna memperkuat persepsi efektifnya program relawan pajak ini, kembali dilakukan wawancara dengan Made AW (37). Beliau menyatakan pengalaman saat didampingi sangat memuaskan dengan respon yang cepat dalam memberikan bantuan pelaporan sehingga terasa lebih mudah serta sangat dituntun dalam pengisiannya. Pelaporan dengan bantuan pendam-pingan oleh pihak relawan pajak dirasa sangat efektif dan sejauh ini sudah sangat bagus dengan jumlah relawan yang memadai dalam memberikan pelayanan kepada WP. Ibu SD (31) juga menyatakan hal serupa. Pelayanan yang diberikan relawan pajak sangat baik dan cepat dalam proses pendampingannya. Perbedaan yang dirasakan saat didampingi oleh relawan pajak adalah proses pelaporan yang lebih mudah dan tidak mengalami kesulitan harus memahami pengisian SPT sendiri. Pelaporan dengan bantuan pendampingan oleh pihak relawan pajak juga dirasa sangat efektif. Hal yang harus diperbaiki bagi relawan pajak mengenai pemahaman lebih mendalam terkait berbagai kasus seperti pelaporan SPT bagi WP berpenghasilan dari dua atau lebih pemberi kerja.

Adanya hasil beberapa wawancara tersebut menyatakan Program Relawan Pajak sangat efektif dalam membantu wajib pajak berkaitan dengan pelaporan SPT. Seluruh WP selaku responden merasa sangat terbantu dengan pendampingan pelaporan yang dilakukan oleh relawan. Namun, dalam menjalankan program ini tentu terdapat kendala seperti yang disampaikan bapak Made AP (31) bahwa diperlukannya perbaikan mengenai ketersediaan infrastruktur jaringan internet yang lebih memadai. Saran ini tentu sangat berharga bagi Tax Center, Kantor Pajak serta DJP sebagai induk dalam bidang ini.

Program Relawan Pajak ini selain memberikan manfaat kepada wajib pajak, juga dapat memberikan manfaat langsung bagi relawan pajak itu sendiri. Program ini adalah wadah pembelajaran terkait perpajakan yang dilakukan secara praktisi. Bapak Gede Adi Yuniarta (40) selaku Wakil Dekan I Fakultas Ekonomi Undiksha yang menaungi bidang akademik mengungkapkan program ini merupakan media yang sangat tepat bagi mahasiswa khususnya di Fakultas Ekonomi dalam menambah wawasan dan mengaplika-sikan ilmu perpajakan yang diperoleh pada saat perkuliahan. Program ini diharapkan dapat dilaksanakan secara berkelanjutan dengan perluasan bidang kerja dan penambahan mahasiswa yang lebih banyak. Hal tersebut dikarenakan rata-rata beberapa rekan menyatakan sangat puas dengan adanya program relawan pajak ini.

Dikaitkan dengan Contrast Theory, kegiatan pendampingan oleh relawan pajak ini telah memperoleh kepuasan Wajib Pajak. Kepuasan Wajib Pajak dapat dilihat melalui hasil kinerja relawan setelah melampaui ekspektasi wajib pajak khususnya dalam hal pendampingan pelaporan SPT WP Orang Pribadi. Kepuasan WP ini berdampak kepada kepatuhan WP dalam melaporkan SPT mereka pada tahun berikutnya dan berdampak pula kepada adanya harapan keberlanjutan program relawan pajak. WP yang didampingi oleh relawan telah memahami langkah-langkah pelaporan SPT sehingga kegiatan ini dapat mereka lakukan kembali secara mandiri di tahun berikutnya. Keberlanjutan program ini sangat diharapkan oleh seluruh responden penelitian yang disampaikan dalam wawancara mereka. Tetapi bapak I Nyoman Putra Yasa (32) selaku Ketua Tax Center Undiksha mengingat arahan dari DJP bahwa kegiatan ini pada dasarnya membantu Wajib Pajak untuk bisa dan terbiasa dalam melapor pajak dengan sistem online, maka pada saat semua Wajib Pajak sudah dapat melaporkan SPT secara mandiri akan berdampak pada diberhentikannya kegiatan ini.

Tingkat kepuasan yang dirasakan oleh wajib pajak berkaitan dengan teori kepatuhan pajak dimana tingkat kepatuhan wajib pajak diharapkan meningkat apabila merasa puas dalam memasukkan SPT-nya secara online dalam melaksanakan kewajibannya sebagai wajib pajak. 
Responden mengharapkan program relawan pajak ini terus berlangsung kedepannya dinilai dari banyaknya wajib pajak yang belum mengerti tata cara penyampaian SPT secara online apalagi yang belum cakap teknologi. Namun keberlangsungan program ini tidak dapat dijamin karena kegiatan ini dibuat dengan tujuan untuk membiasakan Wajib Pajak dalam melaporkan SPTnya secara mandiri dengan sistem online. Jika program relawnan pajak ini dihentikan, diharapkan DJP dapat membuat program serupa kedepannya.

\section{Simpulan}

Berdasarkan pada data yang diperoleh dapat disimpulkan bahwa persepsi Wajib Pajak terkait pendampingan oleh relawan pajak dikatakan efektif untuk dilakukan, terbukti dari kepuasan wajib pajak setelah didampingi. Efektifnya program ini didukung oleh beberapa hasil wawancara Wajib Pajak yang telah dilakukan. Berdasarkan hasil wawancara terhadap 22 responden pada indikator kebermanfaatan yang menggunakan pendampingan relawan pajak, 22 responden merasakan kebermanfaatan program ini. Yang mana apabila dihitung dalam persentase, $100 \%$ responden merasa pendampingan oleh relawan pajak ini bermanfaat. Sedangkan berdasarkan hasil wawancara terhadap 22 responden pada indikator kemudahan yang menggunakan pendampingan relawan pajak, 16 responden merasakan kemudahan program ini dan 6 responden mengalami sedikit kendala. Yang mana apabila dihitung dalam persentase, $73 \%$ responden merasa pendampingan oleh relawan pajak ini memberikan kemudahan.

Untuk memberikan kepuasan pendampingan kepada Wajib Pajak tentu diperlukan peningkatan keterampilan dari masing-masing relawan sehingga memiliki kemampuan yang sama. Wajib Pajak yang telah didampingi tahun ini diharapkan dapat melaporkan SPT-nya ditahun berikutnya, sehingga tingkat kepatuhan pelaporan SPT oleh Wajib Pajak meningkat, artinya, tingkat kepuasan Wajib Pajak ini akan berdampak terhadap kepatuhan Wajib Pajak dalam melaporkan SPT-nya secara mandiri ditahun berikutnya. Bila dikaitkan dengan Contrast Theory, kegiatan pendampingan oleh relawan pajak ini telah memperoleh kepuasan Wajib Pajak. Kepuasan Wajib Pajak dapat dilihat melalui hasil kinerja relawan setelah melampaui ekspektasi wajib pajak khususnya dalam hal pendampingan pelaporan SPT Wajib Pajak Orang Pribadi.

Wajib Pajak merasa sangat terbantu dengan adanya program relawan pajak ini. Relawan pajak sangat runtut dalam memberikan penjelasan berkaitan dengan pengisian SPT sehingga mengerti tata cara pelaporan SPT secara online. Selain itu, keberadaan program ini mengatasi permasalahan antrian panjang di Kantor Pajak untuk pelaporan SPT. Program ini efektif dilakukan setiap tahun karena masuh banyak Wajib Pajak yang belum memahami tata penyampaiannya apalagi yang belum cakap teknologi.

Kegiatan relawan pajak ini sangat bermanfaat bagi WP karena terbantu akan pendampingan para relawan pajak. Program relawan pajak dapat dilaksanakan secara berkelanjutan dengan perluasan bidang kerja untuk membantu Wajib Pajak dalam melaporkan surat pemberitahuan tahunannya. Direktorat Jendral Pajak juga dapat menumbuhkan hubungan dengan Wajib Pajak khusunya lewat penyebaran informasi agar wajib pajak dapat menggunakan sistem e-filling untuk penyampaian surat peberitahuan tahunannya. Sosialisasi bisa melalui media cetak hingga sosial media sehingga mampu menjangkau seluruh wajib pajak. Sistem $e$ filing perlu ditingkatkan agar meminimalisirkan gangguan saat pelaporan surat pemberitahuan serta perlu diperbaiki sehingga bisa digunakan dengan mudah dan tidak terlalu rumit khusunya bagi wajib pajak pemula yang ingin melaporkan SPT tahunan orang pribadi. Bagi universitas, hasil penelitian ini dapat menjadi pedoman atau acuan untuk penelitian selanjutnya. Hasil penelitian ini tentu tidak lepas dari keterbatasan utamanya dari segi metodologi penelitian. Penelitian ini hanya menggunakan wawancara dengan 
menggunakan indikator pertanyaan tanpa menggunakan penilaian dengan skala likert.

\section{Daftar Pustaka}

Agustiningsih, W., \& Isroah, I. (2016). Pengaruh Penerapan E-Filing, Tingkat Pemahaman Perpajakan Dan Kesadaran Wajib Pajak Terhadap Kepatuhan Wajib Pajak Di Kpp Pratama Yogyakarta. Nominal, Barometer Riset Akuntansi Dan Manajemen, 5(2), 107-122. Https://Doi.Org/10.21831/Nominal.V 5i2.11729

Arikunto.S. (2010). Prosedur Penelitian: Suatu Pendekatan. Retrieved From Https://Scholar.Google.Com/Scholar $? \mathrm{Hl}=\mathrm{Id} \& \mathrm{As} \_\mathrm{Sdt}=0 \% 2 \mathrm{C} 5 \& \mathrm{Q}=$ Arikun to $\% 2 \mathrm{C}+\mathrm{S} .+2010 .+$ Prosedur+Peneliti an\%3A+Suatu+Pendekatan+Praktik+ \%28Edisi+Revisi\%29.+Cetakan+Ke14.+Jakarta\%3A+PT+Rineka+Cipta. \&Btng=

DJP (2017). Relawan Pajak. Diakses Melalui Www.Pajak.Go.Id Pada 21 Maret 2020.

DJP (2018). Modul Relawan Pajak. Jakarta: Direktorat P2Humas Dan Direktorat TPB.

DJPPR (2019). Sumber Pembiayaan Negara.

Www.Djppr.Kemenkeu.Go.Id.

Diakses 10 Maret 2020.

DJP. 2020. Tingkatkan Kepatuhan Pajak Jabar II Dorong Program Relawan Pajak. Diakses Melalui Https://Www.Pajak.Go.Id/ Pada 10 April 2020.

Dwianika, A., \& Sofia, I. P. (2019). Relawan Pajak: Bagaimana Pelatihan Pajak Mempengaruhi Kepuasan Wajib Pajak Pada Masyarakat Urban? (Studi Pada Tax Centre Universitas Pembangunan Jaya). Keberlanjutan, 4(2), 1176. Https://Doi.Org/10.32493/Keberlanju tan.V4i2.Y2019.P1176-1191

Dwipayana, MH, Putu Eka DMD, I I Nyoman Putra Yasa. 2017. Pengaruh Program Samsat Corner, Samsat Keliling Dan Kepuasan Wajib Pajak Terhadap Kepatuhan Wajib Pajak
Dalam Membayar Pajak Kendaraan Bermotor (Pkb) (Studi Empiris Pada Kantor Bersama Sistem Administrasi Manunggal Di Bawah Satu Atap (SAMSAT) Denpasar). Jurnal Akuntansi Program S1 (Vol: 8 No: 2 Tahun 2017).

Faisol, M., Dkk. (2019). Jurnal Abdiraja. Jurnal ABDIRAJA, 2(2). Retrieved From

Https://Ejournalwiraraja.Com/Index. $\mathrm{Php} / \mathrm{ADR} /$ Article/View/759

Gekonge, Wallace (2016). Effects Of Electronic Tax System On The Revenue Collection Efficiency Of Kenya Revenue Authority: A Case Of Uasin Gishu County. Imperial Journal of Interdisciplinary Research (IJIR) Vol-2, Issue-4.

Jatmiko, AN. 2006. Pengaruh Sikap Wajib Pajak Pada Pelaksanaan Sanksi Denda, Pelayanan Fiskus Dan Kesadaran Perpajakan Terhadap Kepatuhan Wajib Pajak (Studi Empiris Terhadap Wajib Pajak Orang Pribadi Di Kota Semarang). Masters Thesis, Program Pasca Sarjana Universitas Diponegoro.

Julita, Lidya. 2020. Ada 13 Juta Wajib Pajak Belum Lapor SPT Anda Termasuk?. Diakses Melalui Https://Www.Cnbcindonesia.Com/N ews/20200310144243-4143800/Ada-13-Juta-Wajib-PajakBelum-Lapor-Spt-Anda-Termasuk Pada 16 Maret 2020.

Jotopurnomo, C., \& Mangoting, Y. (2013). (N.D.). Pengaruh Kesadaran Wajib Pajak, Kualitas Pelayanan Fiskus, Sanksi Perpajakan, Lingkungan Wajib Pajak Berada Terhadap Kepatuhan Wajib Pajak Orang Pribadi Di. In Publication.Petra.Ac.Id. Retrieved From

Http://Publication.Petra.Ac.Id/Index. Php/Akuntansi-

Pajak/Article/View/441

Larassaty, Dwi Pinta (2016). Hubungan Antara Kualitas Pelayanan Prima Dengan Citra Positif PT. TASPEN (PERSERO). Jurnal Fakultas Komunikasi Universitas Islam 
Bandung.

Madona, Fitri (2017). Pengaruh Kualitas Pelayanan Tterhadap Kepuasan Nasabah Pada PT. Bank Syariah Mandiri Kantor Cabang 16 Ilir Palembang. UIN Raden Patah Palembang.

Mardiasmo(2011). Perpajakan, Edisi Revisi 2009. Yogyakart... - Google Cendekia. (N.D.). Retrieved December 6, 2020, From Https://Scholar.Google.Com/Scholar $? \mathrm{Hl}=\mathrm{Id} \& \mathrm{As} \_\mathrm{Sdt}=0 \% 2 \mathrm{C} 5 \& \mathrm{Q}=$ Mardia smo.+2011.+Perpajakan\%2C+Edisi+ Revisi+2009.+Yogyakarta\%3A+Pen erbit+Andi\%2C\&Btng=

Sekaran, Uma Dan Roger Bougie(2013). Research Methods For Business: A Skill Building Approach. Fifth Edition. USA: Willey

Suherman, M., Dkk. (2015). Pengaruh Penerapan E-Filing Terhadap Kepatuhan Wajib Pajak Dalam Penyampaian Surat Pemberitahuan (SPT) Tahunan Pada Kantor Pelayanan Pajak Pratama Kota Tasikmalaya. Media Riset Akuntansi, Auditing \& Infomasi Vol. 15 No. 1.

Sugiyono (2007). Metode Penelitian Bisnis. Bandung: Penerbit CV. Alfabeta.

Sugiyono (2012). Metode Penelitian Bisnis. Bandung: Alfabeta

Sugiyono (2012). Metode Penelitian Kuantitatif Kualitatif Dan $R \& D$. Bandung: Penerbit CV. Alfabeta.

Tawas, Viktor Billi Josua, Agus T. Poputra, Robert Lambey (2016). Pengaruh Sosialisasi Perpajakan, Tarif Pajak, Dan Sanksi Perpajakan Terhadap Kepatuhan Pelaporan Spt Tahunan Wajib Pajak Orang Pribadi (Studi Kasus Pada Kpp Pratama Bitung). Jurnal EMBA Vol.4 No.4 Hal 912921.

Tene, JH., Dkk (2017). Pengaruh Pemahaman Wajib Pajak, Kesadaran Pajak, Sanks Perpajakan Dan Pelayanan Fiskus Terhadap Kepatuhan Wajib Pajak ( Studi Empiris Pada Wajib Pajak Orang Pribadi Yang Terdaftar Di KPP
Pratama Manado). JURNAL EMBA: Jurnal Riset Ekonomi, Manajemen, Bisnis Dan Akuntansi Vol 5, No 2 (2017)

Tjiptono, Fandy (2008). Service Management: Mewujudkan Pelayanan Prima Edisi 1. Yogyakarta: Penerbit Andi.

Uly, Yohana Artha(2019). Pelaporan SPT Baru 61,7 \% Tingkat Kepatuhan Wajib Pajak Rendah. Diakses Melalui

Https://Economy.Okezone.Com/ Pada 30 Maret 2020.Undang-Undang Nomor 28 Tahun 2007 Tentang Ketentuan Umum Dan Tata Cara Perpajakan (KUP).

Utami, DW(2019). Relawan Pajak, Jembatan Persuasif Otoritas Pajak. Diakses Melalui Https://Www.Pajakku.Com/Read/5d 9ff1e8b01c4b456747b708/RelawanPajak-Jembatan-Persuasif-OtoritasPajak Pada 30 Maret 2020.

Venkatesh \& Davis, F. D. (2000). A Theoretical Extension of The Technology Acceptance Model: Four Longitudinal Field Studies. Management Science. Vol. 46 No. 2: Pp. 186- 504.

Wulan, R., H., Hasan, A, \& Sofyan, A. (2015). The Influence Of Tax Extension, Tax Compliance, Tax Audits, Tax Collection And Tax Forced Letter With Personal Income Tax Revenue. In Jom. FEKON (Vol. 2) Retrieved From Https://Www.Neliti.Com/Publication s/34107/Pengaruh-Ekstensifikasi-

Pajak-Kepatuhan-Wajib-Pajak-

Pemeriksaan-Pajak-Penagihan

Yasa, I Nyoman Putra, I Putu Hendra Martadinata, I Gede Putu Banu Astawa (2019). Peran Theory Of Planned Behavior Dan Nilai Kearifan Lokal Terhadap Kepatuhan Wajib Pajak: Sebuah Kajian Eksperimen. Jurnal Ekuitas: Jurnal Ekonomi Dan Keuanganvolume 3, Nomor 2 (2019) 